Agrobiogen Gimblt, Hilgerishausen, Germany

BIRGIT KÜHHOLZER and GOTTFRIED BREM

\title{
Somatic nuclear transfer in livestock species
}

\author{
Dedicated to Prof. Dr, Dr. h. c. mult. Horst Kräußlich on the occasion of his \\ $75^{\text {th }}$ birthday
}

\begin{abstract}
Summary
In this review, we discuss the recent advances in somatic cell nuclear transfer (NT) in sheep, cattle, goats, swine and rabbits. Numerous advances have been reported as this technique has developed over the last five years. In the first part of this review, we describe the reported data pertaining to each of the species mentioned above. Theories are offered to explain the different results seen between different species and cell types. One of the main aspects of somatic cell NT, the production of transgenic animals will also be reviewed. Future applications of this powerful technique are discussed. This review concludes with a discussion of some of the problems observed in animals produced using NT as well as possible solutions for these challenges.
\end{abstract}

Key Words: cloning, cattle, small ruminants, pig, rabbit, transgenic

\section{Zusammenfassung}

Titel der Arbeit: Somatischer Kerntransfer bei landwirtschaftlichen Nutztieren

In dieser Literaturlbersicht wird die Entwicklung des somatischen Kemtransfers bei landwirtschaftlichen Nutztieren dargestellt. Seit der Entwicklung dieser Technik vor funf Jahren wurde eine Vielzahl von Berichten veröffentlicht. Erfolge beim Rind, kleinen Wiederkăuer, Schwein und Kaninchen werden beschrieben. Da bei verschiedenen Tierarten und Spenderzellen unterschiedliche Effizienzen bei der Klonierung beobachtet wurden, werden in diesem Manuskript møgliche Grunde dafur diskutiert. Im letzten Abschnitt wird das Hauptaugenmerk auf die Produktion von transgenen Tieren gelegt. Abschließend werden Zukunftsaussichten und møgliche Anwendungsbereiche dieser inmovativen Technik zusammengestellt. Dabei wird auch insbesondere auf Probleme, die im Zusammenhang mit der Klonierung beobachtet werden, eingegangen. Mogliche Grinde und Lösungsvorschläge werden diskutiert.

Schlusselworter: Klonierung, Rind, kleiner Wiederktäuer, Schwein, Kaninchen, transgen

\section{Introduction}

Nuclear transfer procedures originally required donor-cells from undifferentiated early embryonal stages. The only exception was that cells from the inner cell mass (ICM) those cells present at the blastocyst stage of embryo development that are destined to give rise to the fetus itself - could support development and lead to the birth of live offspring (COLLAS and BARNES, 1994).

In 1996 - a milestone in the history of NT - the theory that early embryonal stages were required for successful nuclear transfer became obsolete. CAMPBELL et al. (1996b) were the first to use differentiated embryonal cells, that were kept in culture for several passages as donor cells for NT. These experiments opened the new aera of somatic cell nuclear transfer. New and exciting applications of the NT technique became apparent. It appeared NT could be used to facilitate the production of trans- 
genic animals, enhance the reproductive performance in endangered species (LANZA et al., 2000b) and eventually be used to retrieve extinct species.

From 1996 on, reports of somatic cell nuclear transfer using a variety of differentiated embryonal, fetal and adult donor cells have been published. In this review, we summarize the advances that were achieved in sheep, cattle, goats, swine and rabbits in the last five years (Table 1). We focus on the observed differences in developmental potential observed among different types of donor cells and describe reports of transgenic animals produced with the aid of NT.

Many reviews relating to the field of NT exist (COLMAN, 1999; KÜHHOLZER and PRATHER, 2000; WOLF et al., 2000). The aim of this review is to present a discussion of recent advances in NT from different points of view: cell cycle, cell types, synchronization between cytoplast and donor cell, maturation and in vitrosystems, artificial activation as well as new findings about mitochondrial DNA and telomeres.

\section{Sheep}

As with many other bio-techniques (embryo splitting: WILLADSEN, 1979; NT using blastomeres: WILLADSEN, 1986), the experiments of somatic cell NT succeeded first in the sheep. Compared to cattle, this species has the advantage that its generation interval is significantly shorter; sheep can be maintained with minimal efforts, making experiments more time- and cost-efficient.

CAMPBELL and his colleagues (1996) tried to establish embryonic stem cells from the inner cell mass, but they were not able to maintain them in an undifferentiated state. These embryonic cells were used as donor cells in their NT experiments regardless of their state of differentiation. Most scientists were surprised in 1996 when this group published the birth of five lambs, two of which survived, that were born following the transfer of these NT derived embryos to surrogates (CAMPBELL et al., 1996b). The following year the same group (WILMUT et al., 1997) surprised the public and the scientific community with another unbelievable report: The announcement of the birth of Dolly, a healthy lamb born following transfer of NT embryos, where the donor cells were derived from the differentiated adult mammary gland. Although this experiment was questioned in the beginning by some other groups, a number of reports followed describing comparable findings using somatic cell NT and therefore indirectly proved that the experiments in Wilmut's study were sound and could be replicated. CAMPBELL et al. (1996b) and WILMUT et al. (1997) stressed that the cell cycle arrest in the G0-stage is a major factor that enables reprogramming of a differentiated cell nucleus following NT. It was suggested to culture the cells for a certain period of time in medium with a reduced serum content (starvation), thereby arresting them before DNA-replication (pre-S-phase) in an inactive state (quiescence, G0).

Other factors are also important to improve the efficiency and reduce the cost of producing offspring by NT. One of them is the source of oocytes. It dramatically reduces the expenses of experiments when slaughterhouse ovaries are used as source of oocytes. These oocytes can be matured in vitro thereby eliminating the expenses of maintaining and treating live animals for the sole purpose of oocyte donation. In a comparative study WELLS et al. (1997) investigated the results of somatic nuclear 
transfer when in vitro versus in vivo matured oocytes were used as recipient cytoplasts. When using in vitro matured oocytes, the proportion of embryos that developed to term was reduced compared to in vivo oocytes. In addition the lamb that was derived from in vitro matured oocytes died within $10 \mathrm{~min}$ of delivery. However, this report does demonstrate that in vitro matured oocytes are a viable alternative to using surgically collected, in vivo matured oocytes.

In 1999, SHIELS et al. (1999a, b) analysed the length of telomeres of Dolly, the sheep derived from a mammary gland cell. Telomeres are DNA repeats at the end of eukaryotic chromosomes and they shorten with every cell division, thereby being an indicator of cellular age and senescence. While conventional DNA polymerases are unable to completely replicate telomeres, their lengths can be re-established by an enzyme called telomerase, which is only active in early embryos and germ cells. Telomeres not only protect chromosomal ends from degradation, they also facilitate completion of chromosomal DNA replication and contribute to chromosome positioning within the nucleus (KIERZENBAUM, 2000). Surprisingly, the length of the telomeres in Dolly was comparable to that found in the progenitor mammary tissue and significantly shorter than comparable telomeres of age-matching sheep (SHIELS et al., 1999a, b). They concluded that telomeres in NT embryos could not be restored to full length because these embryos did not pass through the germ line. This would mean, that the genetic age of nuclear transfer animals is significantly older than their phenotypic age. However, this observation of the telomeres in Dolly may not be the general case for all cloned mammals. In the next section the apparent contradictory findings from telomere studies in cloned cattle are discussed. These conflicting results highlight the need for further studies to fully understand the events that occur during NT and to eliminate or minimize problems associated with NT-animals.

Since eukaryotic cells contain two distinct genomes, nuclear DNA and mitochondrial DNA (mtDNA), it was of high interest to determine the origin of the mtDNA in animals produced by somatic NT. Since mtDNA is maternally inherited after normal fertilization, nuclear transfer where the donor cell is fused to the recipient cytoplast should result in mtDNA heteroplasmy. However, when EVANS et al. (1999) analysed the mtDNA of Dolly and nine other NT sheep derived from fetal cells, only oocytederived mtDNA could be detected. Interestingly and similar to analysis of telomeres, controversial results were obtained in cattle (see below).

\section{Cattle}

The first report of the birth of calves generated by somatic NT was published in 1998 by CIBELLI and coworkers. In this study CIBELLI et al. (1998) used cycling cells without any synchronization treatment. Up to that time the prevailing opinion was that donor cells had to be arrested in the presumptive G0-stage of the cell cycle to allow complete reprogramming of differentiated donor cell nuclei. A study by ZAKHARTCHENKO et al. (1999c) that compared cycling and serum starved fetal fibroblasts as donor nuclei revealed NT embryos produced with serum starved cells developed to the blastocyst stage at a higher rate (39\% vs $20 \%$ ) and resulted in more pregnancies after transfer ( $7 / 9$ vs $1 / 3$ ) when compared to cycling cells. In contrast, a higher proportion of pregnancies has lost when embryos were derived from serum- 
starved cells (7/7) compared to cycling cells (0/1). HILL et al. (1999a, 2000b) also found better in vitro development when serum starved fetal cells were used. However, the same group (HILL et al., 2000b) could not find any positive effect of serumstarvation on the development to the blastocyst stage when adult cells were used.

It should be mentioned that every existing synchronization protocol for cycling somatic cells results in a small proportion of synchronized cells positioned in a stage of the cell cycle other than the desired one. Additionally, individual cells used as donor-karyoplasts cannot be analysed prior to NT. Therefore, no one has been able to definitely prove that an embryo or offspring was derived from a donor cell that was in a certain stage of the cell-cycle.

The advances in somatic cell NT are demonstrated by a variety of reports that followed. Within the last three years scientists have been able to produce offspring derived from primordial germ cells (ZАKHARTCHENKO et al., 1999b), embryonic germ cells (BRINK et al., 2000), various newborn and adult tissues (KATO et al., 1998; WELLS et al., 1999; KATO ct al., 2000) and most surprisingly, even from white blood cells (GALLI et al., 1999).

In contrast to findings in sheep (SHIELS et al., 1999a, b), LANZA et al. (2000a) found that NT procedures in cattle were capable of resetting and even extending the life span of somatic cells. These conflicting results could be attributed to species-specific differences in telomerase activity in early embryos, or to the use of donor-cells at different stages of their lifespan. While the study in sheep used serum-starved cells, LANZA et al. (2000a) used fibroblast cells that were close to cellular senescence. Accordingly, BETTS et al, (2001) found that cell passage and culture in medium with low serum concentrations reduced telomerase activity by 30 to $50 \%$, compared to nontreated cells. It was demonstrated that cloned embryos inherit genomic modifications (shortened telomeres according to age and culture period) from their donor-cells. However, these modifications are subsequently reversed during early development of cloned embryos, thereby being reprogrammed and rejuvenated. Another report strengthens these findings. In cattle XU and YANG (2001) analysed telomerase in bovine NT-embryos and detected its activity in all stages, with highest levels found at the blastocyst stage.

KUBOTA et al. (2000) were able to produce live offspring derived from donor cells after long-term culture, indicating cellular aging must be reversed to a certain extent in these experiments. It was also possible to produce live offspring from aged individuals (21 year-old bull), which also indicates that NT might successfully reverse aging (HILL et al., 2000b).

STEINBORN et al. (2000) analyzed mtDNA of calves derived from fetal and adult fibroblasts as well as mammary gland cells. In seven out of ten analysed clones the donor-recipient ratios of parental mtDNAs before fusion remained the same throughout embryogenesis and development to term. However, tissues of the other 3 clones showed significant reduction or absence of donor mtDNA due to unknown mechanisms. This is in contrast to findings in sheep where no mtDNA heteroplasmy could be detected in somatic NT-offspring. The report by STEINBORN et al, (2000) suggests that miDNA heteroplasmy does not impede normal development and may be related to the high pregnancy losses observed in somatic NT-studies. It also indicates 
that there might be a variation in the mechanisms involved in the inheritance of mtDNA. Therefore, further studies are required to enlarge our understanding of this subject.

\section{Goats}

Only two reports on somatic NT in goats have been published so far. In the first report BAGUISI et al. (1999) compared the use of metaphase II (MII) versus pre-activated oocytes as recipient cytoplasts. Both stages were recovered out of the oviducts from superovulated does. Some of the recovered oocytes already extruded a second polar body, which was interpreted as being a morphological sign of pre-activation. It was concluded that the flushing of the oviducts and short-term culture in $\mathrm{Ca}^{2+}$-containing medium probably induced activation. Another group of oocytes was pre-activated by ethanol treatment. While one offspring was derived from a MII-oocyte and a set of twins was born after using self-activated oocytes, no term-development was observed when ethanol-activated oocytes were used as recipient cytoplasts. Since only a low number of NTs were reported, it cannot be excluded, that also the use of chemically pre-activated oocytes might result in live offspring. For NT using embryonic blastomeres that are mainly in S-phase of the cell-cycle, it was found that pre-activated cytoplasts are the universal recipient (CAMPBELL et al., 1996a). In pre-activated cytoplasts, the DNA is replicated according to the cell-cycle stage and, therefore correct ploidy can be maintained. However, the use of differentiated donor cells seems to require high concentrations of maturation/mitosis/meiosis promotion factor (MPF) to be properly reprogrammed (CAMPBELL, 1999). This and the fact that the majority of differentiated cultured cells are in pre-S-phase explain, why most scientists prefer the use of the combination of MII-cytoplasts and donor cells in G1 or G0.

In contrast to the report by BAGUISI et al. (1999) who used in vivo matured oocytes, KEEFER et al. (2001) recovered immature oocytes by laparoscopic follicular aspiration and subsequently used them as recipient cytoplasts after in vitro maturation. As another difference, KEEFER et al. (2001) synchronized their donor-fibroblasts by culture to confluency in addition to subsequent culture in low serum, thereby increasing the probability that cells in the G0-stage were used. Six kids were born from 2 different cell lines; three of them died within one month after delivery but the remaining kids appear to be healthy and are presently older than one year.

\section{Swine}

Since the first NT-piglet derived from a blastomere was born (PRATHER et al., 1989), many years passed without a major success in porcine nuclear transfer. Although there were serious efforts in many groups to produce pigs by somatic nuclear transfer, results were not comparable to those in sheep or cattle. It became clear, that porcine oocytes are harder to activate when compared to other species; therefore, different protocols were developed that improved this part. Besides electrical activation, a variety of chemical treatments were tested. In contrast to fertilization, which is followed by $\mathrm{Ca}^{2+}$-oszillations, electrical activation induces only a single $\mathrm{Ca}^{2+}$-transient (reviewed by MACHATY and PRATHER, 1998). MACHATY et al. (1997) finally 
established a protocol for chemical activation which mimicked fertilization-events: The sulfhydryl reagent thimerosal induced repeated $\mathrm{Ca}^{2+}$ transients, and in combination with subsequent incubation in dithiotreitol (DTT) porcine oocytes were successfully activated. Also nuclear transfer embryos that were activated according to this protocol developed to the blastocyst stage (KUHHOLZER et al., 2000). However, no development to term could be established.

Finally in 2000, two independent groups were able to produce piglets by somatic NT. In the first report (POLEJEAVA et al., 2000) the technique of serial NT was used to circumvent the problem of artificial activation. After the initial NT using granulosa cells reconstructed embryos were cultured over night and subsequently the pronuclei of the developing embryos were removed and fused to enucleated zygotes. Thereby the cytoplast was activated by fertilization and provided optimal conditions for the transferred pronucleus. After transfer of 400 embryos into 7 recipients five healthy piglets were born. In contrast to this report, ONISHI et al, (2000) used fetal fibroblasts as nuclear donors and transferred them by direct intracytoplasmic injection. Three to four hours after injection, reconstructed embryos were activated by exposure to electrical pulses, followed by incubation in cytochalasin-B to prevent cytokinesis. This delayed activation enabled a longer exposure of the donor nucleus to the MII-cytoplast (high levels of MPF), which should facilitate correct/complete reprogramming. Similar to Polejaeva's report, where embryos were transferred immediately (within 2 hours) after fusion, Onishi transferred 110 embryos at an early stage (2- to 8-cell stage) into 4 recipients, which resulted in the birth of a single piglet. In both studies, ovulated oocytes were used as recipient cytoplasts, which provided the optimal maturation. However, to reduce the cost of NT, it is necessary to establish in vitro systems that are suitable to provide sufficient numbers of matured oocytes for NT. Shortly after the first two reports of somatic NT in the pig, BETTHAUSER et al. (2000) were able to produce nuclear transfer piglets from in vitro matured sow-oocytes. Another big success in their study was, that the protocol for NT was reproducible and NT-piglets derived from fetal fibroblasts and cells from the genital ridge were born from two separate pregnancies with another five ongoing pregnancies reported. In addition to the successful production of piglets, BETTHAUSER et al. (2000) investigated the feasibility of sow versus gilt oocytes for their in vitro system: for both, IVF and NT about twice as much embryos developed to blastocysts when sow oocytes were used as opposed to gilt oocytes, an observation that was also described by KÜHHOLZER et al. (2001). While neither of these reports describe significant changes of existing protocols, it is obvious that the management of recipient herds, synchronization and embryo transfer might have been an underestimated factor for the success of producing NT-offspring. An increase in the number of embryos transferred per recipient (more than 100 ) resulted in a significant improvement of the efficiency of somatic NT.

Surprisingly, after more than 10 years of failure, a variety of groups succeeded to produce live NT-piglets using different donor cell types and different activation protocols.

Rabbits

Interestingly, so far there is no report of the successful production of live offspring 
after somatic nuclear transfer in rabbits. This is especially surprising, since the rabbit is a species with a very high fecundity when compared to other livestock species and gives outstanding efficiencies in other bio-techniques like pronuclear injections or superovulation and embryo transfer in general (reviewed by BESENFELDER et al., 1998). When using the established techniquc of NT of embryonic blastomeres, no major problems were observed like it was in the pig (HEYMAN et al., 1990). However, there are still significant improvements required in this species. The lack of NT-offspring is also in contrast to the good in vitro development of rabbit parthenogenetic embryos or embryos produced by somatic NT (MITALIPOV et al., 1999; YIN et al., 2000; DINNYES et al., 2001; NOWSHARI et al., submitted). This contradiction points out clearly, that it is a must, that new or mores sensitive analysis and detection methods have to be found to be able to better evaluate embryos. So far we have the opportunity to evaluate embryos morphologically, count the number of nuclei of various embryonal stages, differentiate between inner cell mass and trophectoderm by differential staining or analyse the expression of a variety of genes. But still, all of these methods are not sufficient to predict if embryos will be capable of developing into viable fetuses and subsequently result in live, healthy offspring.

Table I

Somatic NT in livestock using different types of differentiated donor cells (Somatischer Kerntransfer beim Nutzlier unter Verwendung von verschiedenen differenzierten Zelliypen als Donorkaryoplast)

\begin{tabular}{|c|c|c|c|c|c|}
\hline Species & Donor-cells & $\begin{array}{l}\text { Cell-culture } \\
\text { conditions }\end{array}$ & Maturation & Offspring & Reference \\
\hline \multirow[t]{5}{*}{ Sheep } & Embryonic cells & scrum-starved & in vivo & yes & Campbell et al, 1996b \\
\hline & Embryonic cells & serum-starved & in vitro & yes* & Wells et al., 1997 \\
\hline & Embryonic cells & serum-staryed & in vivo & yes & Wells et al., 1997, 1998 \\
\hline & Fetal fibroblasts & serum-starved & in vivo & yes & Wilmut et al, 1997 \\
\hline & Mammary gland cells & serum-starved & in vivo & yes & Wilmut et al., 1997 \\
\hline \multirow[t]{12}{*}{ Cattle } & Fetal fibroblasts & cycling & in vitro & yes & Cibelli et al., 1998 \\
\hline & Fetal germ cells & freshly isolated & in vitro & yes* & Zakhartchenko et al., $1999 \mathrm{~b}$ \\
\hline & Embryonic germ cells & $\mathrm{n} / \mathrm{a}$ & in vitro & yes & Brink et al., 2000 \\
\hline & Newborn skin cells & serum starved & in vitro & yes & Kato et al, 2000 \\
\hline & Newborn liver cells & serum starved & in vitro & yes & Kato et al., 2000 \\
\hline & Mammary gland cells & serum-starved & in vitro & yes & Zakhartchenko et al., 1999a \\
\hline & Adult skin fibroblasts & serum-starved & in vitro & yes** & Zakhartchenko et al,, 1999a \\
\hline & Adult skin fibroblasts & serum-starved & in vitro & yes & Kato et al., 2000 \\
\hline & Mural granulosa cells & serum-starved & in vitro & yes & Wells et al., 1999 \\
\hline & Cumulus cells & serum-starved & in vitro & yes & $\mathrm{tal}, 1998$ \\
\hline & Oviductal cells & serum-starved & in vitro & yes & Kato et al., 1998 \\
\hline & Leukocytes & frozen-thawed & in vitro & yes & Galli et al., 1999 \\
\hline \multirow[t]{2}{*}{ Goat } & Fetal fibroblasts & serum-staryed & in vivo & yes & Baguisi et al., 1999 \\
\hline & Fetal fibroblasts & confluent+starved & in vitro & yes & Keefer et al., 2001 \\
\hline \multirow[t]{4}{*}{ Pig } & Granulosa cells & confluency & in vivo & yes & Polejaeva et al, 2000 \\
\hline & Fetal fibroblasts & $\begin{array}{l}16 \mathrm{~d} \text { w/o media } \\
\text { replenishment }\end{array}$ & in vivo & yes & Onishiet al., 2000 \\
\hline & Fetal fibroblasts & confluency & in vitro & yes & Betthauser et al., 2000 \\
\hline & Genital ridge cells & confluency & in vitro & yes & Betthauser et al., 2000 \\
\hline \multirow[t]{3}{*}{ Rabbit } & Cumulus cells & serum-starved & in vivo & no & Yin et al., 2000 \\
\hline & Adult fibroblasts & serum-starved & in vivo & no & Dinnyes et al., 2001 \\
\hline & Fetal fibroblasts & serum-starved & in vivo & no & Nowshari et al., submitted \\
\hline
\end{tabular}




\section{Production of transgenic animals}

Transgenic farm-animals have been produced since 1985 (BREM et al., 1985; HAMMER et al., 1985) by microinjection into the pronuclei of zygotes, however, the efficiency remained low. Somatic NT using transgenic donor cells also prevents the incidence of mosaicism and - when using homologous recombination - of insertional mutations or problems of varying gene-expression due to position effects. The main interests in generating transgenic animals lies in the production of pharmaceuticals or other proteins of interest, supply of organs for xenotransplantation or modifications that improve features that are of economic interest (reviewed by FRENCH et al,, 1998; BRINK et al., 2000; PIEDRAHITA, 2000; WOLF et al., 2000).

There are many reports about in vitro development of NT-embryos derived from transfected donor-cells. In contrast, reports of transgenic NT-offspring are limited. As reviewed in this manuscript, lots of different cell-types resulted in the birth of offspring after somatic NT, however, fetal fibroblasts seem to be the cell-type of choice for the production of transgenic NT-animals with the exception of one report using transfected embryonic germ cells (Table 2). The culture period of donor-cells gives the opportunity of transfection and subsequent analysis prior to use in nuclear transfer. There is also the possibility to get multiple identical offspring from (male) transgenic founder animals by breeding females and recover their fetuses. From such fetuses one can establish fetal cell lines and use them (after analysis to confirm the presence of the transgene) as donors for NT. The first report using this system was published by BAGUISI et al. (1999). They produced transgenic goats from fetal fibroblasts that were derived from a transgenic fetus, carrying the recombinant human antithrombin III (rhAT). This method has the disadvantage that one does not want to sacrifice a female founder to obtain fetal tissue, in addition to the requirement of existing transgenic animals to begin with.

The in vitro transfection of an existing cell line is a more advanced technology. Although successful modification of cells with subsequent selection results in cells of a higher passage number and more generation intervals, there are still reports of live transgenic animals that were derived from donor cells, that were transfected in vitro. Again the first animal produced by somatic nuclear transfer using transfected fetal fibroblasts was a sheep. SCHNIEKE et al. (1997) transfected fetal fibroblasts with the gene for the human blood-clotting factor IX (FIX) and subsequently used these cells for NT. The lambs that were generated in this study not only integrated, but also expressed the transgene.

CIBELLI et al. (1998) reported the birth of the first transgenic calves that were produced by somatic nuclear transfer. They used a marker gene ( $\beta$-galactosidaseneomycin resistance, B-GEO) to prove the feasibility of this technique in cattle. After these initial experiments further studies followed that produced a transgenic goal (enhanced green fluorescent protein - eGFP: KEEFER et al,, 2001) and a transgenic calf ( $\mathrm{p} 77$ - bovine prochymosin: ZAKHARTCHENKO et al., submitted) derived from transfected cells. In contrast to reports in other species, this transgenic goat did not express the transgene.

Since the transfection method used in the reports mentioned above resulted in random integration and a viable number of copies that were integrated, the use of homologous 
recombination for the production of transgenic animals is of great interest. Homologous recombination or gene targeting require long-term culture and result in a high number of population doublings and were therefore only successfully performed in mural embryonic stem (ES) cells. ES cells are not yet available in livestock. Thus, scientists tried to modify fetal fibroblasts by homologous recombination. Again the first success was reported in sheep: McCREATH et al. $(2000 \mathrm{a}, \mathrm{b})$ were able to establish efficient and reproducible gene targeting in fetal fibroblasts. A therapeutic transgene (human $\alpha 1$-antitrypsin, $\Lambda$ TT) was successfully inserted at the ovine $\alpha .1(\mathrm{I})$ procollagen locus, These gene-targeted cells were subsequently used in NTexperiments that resulted in the birth of 12 lambs, of which three survived. Table 2 summarizes the different techniques that resulted in the birth of transgenic NToffspring.

Table 2

Production of transgenic livestock by using somatic nuclear transfer (Erstellung transgener Nutztiere mittels somatischem Kemtransfer)

\begin{tabular}{|c|c|c|c|c|c|}
\hline Species & Donor-cells & Transfection method & Transgene & Expression & Reference \\
\hline Sheep & Fetal fibroblasts & Lipofectamine & F IX & yes & Schnieke et al., 1997 \\
\hline \multirow{3}{*}{ Cattle } & Fetal fibroblasts & Homologous recombination & ATT & yes & McCreath et al., 2000a,b \\
\hline & Fetal fibroblasts & $\mathrm{n} / \mathrm{a}$ & B-GEO & yes & Cibelli et al, 1998 \\
\hline & Embr. germ cells & $n / a$ & $\mathrm{n} / \mathrm{a}$ & $n / a$ & Brink et al, 2000 \\
\hline \multirow{3}{*}{ Goats } & Fetal fibroblasts & Trans-Fast Reagent & p77 & $n / a$ & Zakhartchenko et al., 2001 \\
\hline & Fetal fibroblasts & Transgenic fetus & thAT & yes & Baguisi et al., 1999 \\
\hline & Fetal fibroblasts & Lipofectamine & eGFP & no & Keefer et al., 2001 \\
\hline
\end{tabular}

\section{Future perspectives}

Unfortunately, and regardless of the big accomplishments in the last couple of years, it cannot be ignored, that there are still many problems in connection with nuclear transfer (HILL et al., 1999a, b; RENARD et al., 1999; HILL et al., 2000b; NUMABE et al., 2000). Not only a high percentage of pregnancies are lost but also a variety of abnormalities are found in NT-offspring. Before the technology reaches a state, where its use will be practical and cost-efficient, significant improvements in maturation, donor-cell preparation, activation and in vitro systems are required. It is essential, that protocols for defined in vitro systems will be developed and/or improved, so that variable factors can be minimized.

New studies on gene expression (MEMILI and FIRST, 1999; DeSOUSA et al., 1999; LAURINCIK et al., 2000; YOUNG et al,, 2001) are a start in expanding the knowledge and understanding of reprogramming and subsequent events that happen during and after somatic cell nuclear transfer.

\section{References}

BAGUISI, A.; BEHBOODI, E.; MELICAN, D.T.; POLLOCK, J.S.; DESTREMPES, M.M.; CAMMUSO, C.; WILLIAMS, J.L.; NIMS, S.D.; PORTER, C.A.; MIDURA, P.; PALACIOS, M.J.; AYRES, S.L.; DENNISTON, R.S.; HAYES, M.L.; ZIOMEK, C.A.; MEADE, H.M.; GODKE, R.A.; GAVIN, W.G.; OVERSTRÖM, E.W::
ECHELARD, Y.:

Production of goats by somatic cell nuclear transfer. Nat. Biotech, 17 (1999), 456-461 
BETTHAUSER, J.; FORSBERG, E;; AUGENSTEIN, M.; CHILDS, L.; EILERSTEN, K.; ENOS, J.; FORSYTHE, T.; GOLUEKE, P.; JURGELLA, G.; KOPPANG, R.; LESMEISTER, T.; MALLON, K.; MELL, G.; MISICA, P.; PACE, M.; PFISTER-GENSKOW, M.; STRELCHENKO, N.; VOELKER, G.; WATT, S.; THOMPSON, S.; BISHOP, M.:

Production from cloned pigs from in vitro systems. Nat. Biotech. 18 (2000), 1055-1059

BESENFELDER, U.; AIGNER, B.; MÜLLER, M.; BREM, G.:

Generation and application of transgenics rabbils. In: CID-ARREGUI, A.; GARCIA-CARRANCA, A.: Ed. Microinjection and transgenesis - strategies and protocols. Springer-Verlag, Heidelberg (1998), $561-586$

BETTS, D.H.; BORDIGNON, V.; HILL, J.R.; WINGER, Q.; WESTHUSIN, M.E.; SMITH, L.C.; KING, W.A.: Reprogramming of telomerase activity and rebuilding of telomere length in cloned cattle. Proc. Natl. Acad. Sci. 98 (2001), 1077-1082

BREM, G.; BRENIG, B.; GOODMAN, H.M.; SELDEN, R.C.; GRAF, F.; KRUFF, B.; SPRINGMANN, K.; HONDELE, J.; MEYER, J.; WINNACKER, E.L.; KRÄUBLICH, H.: Production of transgenic mice, rabbits and pigs by microinjection into pronuclei. Zuchthygiene 20 (1985), 251-252

BRINK, M.F.; BISHOP, M.D;; PIEPER, F.R.; Devcloping efficient strategies for the generation of transgenic cattle which produce biopharmaceuticals in milk. Theriogenology $53(2000), 139-148$

CAMPBELL, K.H.S. Nuclear equivalence, nuclear transfer and the cell cycle. Cloning 1 (1999), 3-15

CAMPBELL, K.H.S.; LOI, P.; OTAEGUI, P.J.; WILMUT, I.: Cell cycle co-ordination in embryo cloning by nuclear transfer. Rev. Reprod. 1 (1996a), 40-46

CAMPBELL, K.H.S.; MCWHIR, J.; RITCHIE, W.A.; WILMUT, I.: Sheep cloned by nuclear transfer. Nature 380 (1996b), 64-66

CIBELLI, J.B.; STICE, S.L.; GOLUEKE, P.J.; KANE, J.J; JERRY, J; BLACKWELL, C;; PONCE de LEON, F.A.; ROBL, J.M.: Cloned transgenic calves produced from nonquiescent fetal fibroblasts. Science 280 (1998), 1256-1258

COLLAS, P: BARNES, F.L.: Nuclear transplantation by microinjection of inner cell mass and granulosa cell nuclei. Mol. Reprod. Dev. 38 (1994), 264-267

COLMAN, A: Somatic cell nuclear transfer in mammals: Progress and applications. Cloning 1 (2000), 185-200

DESOUSA, P.A.; WINGER, Q.; HILL, J.R.; JONES, K.; WATSON, A.J.; WESTHUSIN, M.E.: Reprogramming of fibroblast nuclei after transfer into bovine oocytes. Cloning 1 (1999), 63-69

DINNYES, A.; DAI, Y.; BARBER, M.; LIU, L.; XU, J.; ZHOU, P; YANG, X.: Development of cloned embryos from adult rabbit fibroblasts: effect of activation treatment and donor cell preparation. Biol. Reprod. 64 (2001), 257-263

EVANS, M.J,; GURER, C.; LOIKE, J.D; WILMUT, 1; SCHNIEKE, A.E.; SCHON, E.A.: Mitochondrial DNA genotypes in nuclear transfer-derived cloned sheep. Nature Genet. 23 (1999), 9093

FRENCH, A.J.; GREENSTEIN, J.L.; LOVELAND, B.E.; MOUNTFORD, P.S.: Current and future prospects for xenotransplantation. Reprod. Fertil. Dev. 10 (1998), 683-696

GALLI, C.; DUCHI, R; MOOR, R.M.; LAZZARI, G.: Mammalian leukocytes contain all the genetic information necessary for the development of a new individual. Cloning 1 (1999), 161-170

HEYMAN, Y.; CHESNE, P.; RENARD, J.P.: Full-term reprogramming of frozen embryonic nuclei after nuclear transfer in the rabbit. Comp. Rend Acad. Sci. Series III 331 (1990), 32I-326

HILL, J.R; BURGHARDT, R.C.; JONES, K.; LONG, C.R; LOONEY, C.R;; SHIN, T; SPENCER, T.E.; THOMPSON, J.A;; WINGER, Q.A.; WESTHUSIN, M.E.: Evidence for placental abnormalities as the major cause of mortality in first-trimester somatic cell cloned bovine fetuses. Biol. Reprod, 63 (2000), 1787-1794

HILL, J.; WINGER, Q.; JONES, K.; KELLER, D; KING, W.A.; WESTHUSIN, M. The effect of donor cell scrum starvation and oocyte activation compounds on the development of somatic cell cloned embryos, Cloning 1 (1999), 201-208 
HILL, J.R.; ROUSSEL, A.J; CIBELLI, J.B;; EDWARDS, J.F.; HOOPER, N.L.; MILLER, M.W.

THOMPSON, J.A.; LOONEY, C.R.; WESTHUSIN, M.E.; ROBL, J.M., STICE, S.L.: Clinical and pathological features of cloned transgenic calves and fetuses ( 13 case studies), Theriogenology 51 (1999), 1451-1465

HILL, J.R.; WINGER, Q.A.; LONG, C.R.; LOONEY, C.R.; THOMPSON, J.A.; WESTHUSIN, M.E.: Development rates of male bovine nuclear transfer embryos derived from adult and fetal cells. Biol. Reprod. 62 (2000), I135-1140

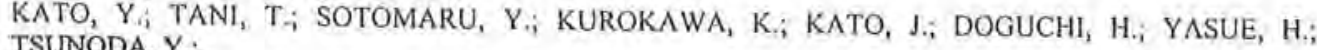
TSUNODA, $Y_{\text {: }}$ Eight calves cloned from somatic cells of a singlc adult. Science 282 (1998), 2095-2098

KATO, Y.; TANI, T.; TSUNODA, Y.: Cloning of calves from various somatic cell types of male and female adult, newborn and fetal cows. I. Reprod, Fertil. 120 (2000), 231-237

KEEFER, C.L.; BALDASSARRE, H.; KEYSTONE, R.; WANG, B.; BHATIA, B.; BILODEAU, A.S.; ZHOU, J.F.; LEDUC, M.; DOWNEY, B.R.; LAZARIS, A.; KARATZAS, C.N.: Generation of dwarf coat (capra hircus) clones following nuclear transfer with transfected and nontransfected fetal fibroblasts and in vitro-matured oocytes. Biol. Reprod. 64 (2001), 849-856

KIERSZENBAUM, A.L.

Telomeres; more than chromosomal non-sticking ends. Mol. Reprod. Fertil. 57 (2000), 2-3

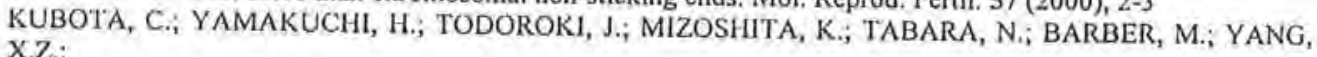
X.Z;

Six cloned calves produced from adult fibroblast cells after long-term culture. Proc. Natl. Acad. Sci. 97 (2000), 990-995

KÜHHOLZER, B.; HAWLEY, R.J.; LAI, L.; KOLBER-SIMONDS, D.; PRATHER, R.S.

Clonal lines of transgenic fibroblast cells derived from the same fetus result in different development when used for nuclear transfer in pigs. Biol. Reprod, (2001), in press

KÜHHOLZER, B.; PRATHER, R.S.: Advances in livestock nuclear transfer. J. Exp. Biol. Med. 224 (2000), 240-245

KÜHHOLZER, B.; TAO, T.; MACHATY, Z.; HAWLEY, R.J.; GREENSTEIN, J.L.; DAY, B.N.; PRATHER, R.S.:

Production of transgenic porcine blastocysts by intracytoplasmic injection of fetal fibroblast cells. Mol. Reprod. Dev. 56 (2000), 14S-148

LANZA, R.P.; CIBELLI, J.B.; BLACKWELL, C.; CRISTOFALO, V.J.; FRANCIS, M.K.; BAERLOCHER,

G.M.; MAK, J.; SCHERTZER, M.; CHAVEZ, E.A.; SAWER, N.; LANSDORP, P.M.; WEST, M.D.:

Extension of life-span and telomerc length in animals cloned from senescent somatic cells. Science 288 (2000a), 665-669

LANZA, R.P.; CIBELLI, J.B; DIAZ, F; MORAES, C.T;; FARIN, P.W.; FARIN, C.E; HAMMER, C.J.; WEST, M.D.; DAMIANI, P.:

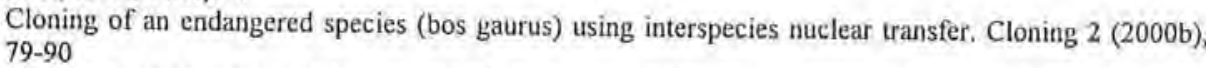

LAUURINCIK, J.; ZAKHARTCHENKO, V.; AVERY, B.; STOJKOVIC, M.; BREM, G.; WOLF, E.; MÜLLER, M.; HYTTEL, P.:

Activation of ribosomal RNA genes in pre-implantation in vitro-produced and nuclear transfer bovine embryos. Reprod. Dom. Anim. 35 (2000), 255-259

MACHATY, Z.; PRATHER, R.S.:

Strategies for activating nuclear transfer oocytes. Reprod. Fertil. Dev, 10 (1998), 599-613

MACHATY, Z,; WANG, W.H.; DAY, B.N.; PRATHER, R.S.:

Complete activation of porcine oocytes induced by the sulfhydryl reagent, thimerosal. Biol. Reprod. 57 (1997), 1123-1127

MCCREATH, K.J.; HOWCROFT, J;; CAMPBELL, K.H.S ; COLMAN, A.; SCHNIEKE, A.E.; KIND.; Production of gene-targeted sheep by nuclear transfer from cultured somatic cells. Nature $405(2000)$,
$1066-1069$

MCCREATH, K.J.; HOWCROFT, J.; CAMPBELL, K.H.S.; COLMAN, A.; SCHNIEKE, A.E.; KIND.; Production of gene-targeted sheep by wuclear transfer from cultured somatic cells (correction, addition). Nature 408 (2000), 120

MEMILl, E.; FIRST, N.L.:

Control of gene expression at the onset of bovine embryonic development. Biol. Reprod. 61 (1999), $1198-1207$ 
MITALIPOV, S.M.; WHITE, K.L.; FARRAR, V.R.; MORREY, J.; REED, W.A.:

Development of nuclear transfer and parthenogenetic rabbit embryos activated with inositol $1,4,5$ triphosphate. Biol. Reprod, 60 (1999), 821-827

NOWSHARI, M.A.; BESENFELDER, U.; MÖBLACHER, G.; BREM, G.: Nuclear transfer with somatic cells in rabbits. Submilted, 2001

NUMABE, T.; OIKAWA, T.; KIKUCHI, T.; HORIUCHI, T.: Birth weight and birth rate of heavy calves conceived by transfer of in vitro or in vivo produced embryos. Anim. Reprod. Sci. 64 (2000), 13-20

ONISHI, A.; IWAMOTO, M.; AKITA, T.; MIKAWA, S.; TAKEDA, K.; AWATA, T.; HANADA, H.; PERRY, A.C.F.: Pig cloning by microinjection of fetal fibroblast nuclei. Science 289 (2000), 1188-1190

PIEDRAHITA, J,A.: Targeted modification of the domestic animal genome. Theriogenology 53 (2000), 105-116

POLEJAEVA, I.A.; CHEN, S.H.; VAUGHT, T.D.; PAGE, R.L.; MULLINS, J.; BALL, S.; DAI, Y.; BOONE, J.; WALKER, S.; AYARES, D.L.; COLMAN, A.; CAMPBELL, K.H.S.: Cloned pigs produced by nuclear transfer from adult somatic cells. Nature $407(2000), 86-90$

PRATHER, R.S.; SIMS, M.M.; FIRST, N.L.: Nuclear transfer in early pig embryos. Biol. Reprod. 41 (1989), 414-4I8

RENARD J.P.; CHASTANT, S.; CHESNE, P.; RICHARD, C.; MARCHAL, J.; CORDONNIER, N.; CHAVATTE, P. ; VIGNON, X. : Lymphoid hypoplasia and somatic cell cloning. Lancet 353 (1999), 1489-1491

SCHNIEKE, A.E.; KIND, A.J.; RITCHIE, W.A.; MYCOCK, K.; SCOTT, A.R.; RITCHIE, M; WILMUT, I.; COLMAN, A.; CAMPBELL, K.H.S.: Human factor IX transgenic sheep produced by transfer of nuclei from transfected fetal fibroblasts. Science 278 (1997), 2130-2133

SHIELS, P.G.; KIND, A.J;; CAMPBELL, K.H.S.; WILMUT, I.; WADDINGTON, D; COLMAN, A.; SCHNIEKE, A.E.: Analysis of telomere length in Dolly, a sheep derived by nuclear transfer. Cloning 1 (1999a), 119-12S

SHIELS, P.G; KIND, A.J.; CAMPBELL, K.H.S.; WADDINGTON, D.; WILMUT, I; COLMAN, A; SCHNIEKE, A.E.: Analysis of telomere lengths in cloned sheep. Nature 399 (1999b), 316-317

STEINBORN, R.; ZAKHARTCHENKO, V.; ACHMANN, R.; SCHERNTHANER, W; STOIKOVIC, M.; WOLF, E.; MULLER, M.;BREM, G.: Mitochondrial DNA hetcroplasmy in cloned cattle produced by fetal and adult ceft cloning. Nature Genet. 25 (2000), 255-257

WELLS, D.N; MISCIA, P.M.; DAY, A.M.; PETERSON, A:J:; TERVIT, H.R.: Cloning sheep from cultured embryonic cells. Reprod. Fertil. Dev. 10 (1998), 615-626

WELLS, D.N;; MISCIA, P.M.; DAY, A.M.; TERVIT, H.R. Production of cloned lambs from an established cell line: a comparison between in vivo- and in vitromatured oocytes. Biol. Reprod. 57 (1997), 385-393

WELLS, D.N.; MISICA, P.M.; TERVIT, H.R.: Production of cloned calves following nuclear transfer with cultured adult mural granulosa cells. Biol. Reprod. 60 (1999), 996-1005

WILL.ADSEN, S.M. $\Lambda$ method for culture of micromanipulated sheep embryos and its use to produce monozygotic twins. Nature 277 (1979), 298-300

WILLADSEN, S.M.: Nuclear transplantation of sheep embryos. Nature 320 (1986), 63-65

WILMUT, I.; SCINIEKE, A.E; MCWIHIR, J.; KIND, A.J,; CAMPBELL, K.H.S.: Viable offspring derived from fetal and adult mammalian cells. Nature 358 (1997), 810-813

WOLF, E; SCHERNTHANER, W; ZAKHARTCHENKO, V; PRELLE, K.; STOJKOVIC, M.; BREM, G.: Transgenic technology in farm animals - progress and perspectives. Exp. Phys. 85 (2000), 615-625

XU, J.; YANG, X.Z.: Telomerase activity in early bovine embryos derived from parthenogenetic activation and nuclear transfer. Biol. Reprod. 64 (2001), 770-774

YIN, X.I.; TANI, T.; KATO, Y.; TSUNODA, Y.: Development of rabbit parthenogenctic oocytes and nuclear transferred oocytes receiving cultured cumulus cells. Theriogenology 54 (2000), 1469-1476 
YOUNG, L.E.; FERNANDES, K.; McEVOY, T.G.; BUTTERWITH, S.C.; GUTIERREZ, C.G.; CAROLAN, C.; BROADBENT, P.J ; ROBINSON, J.J; WILMUT, L; SINCLAIR, K.D.:

Epigenetic change in IGF2R is associated with fetal overgrowth after sheep embryo culturc. Nature Genet. 27 (2001), 153-154

ZAKHARTCHENKO, V;; ALBERIO, R.; STOJKOVIC, $M_{\text {; }}$ PRELLE, $K_{. ;}$SCHERNTHANER, W.; STOJKOVIC, P; WENIGERKIND, H.; WANKE, R.; DÜCHLER, M.; STEINBORN, R.; MULLER, M.; BREM, G.; WOLF, E..

Adult cloning in cattle: Potential of nuclei from a permanent cell line and from primary cultures. Mol. Reprod. Dev. 54 (1999), 264-272

ZAKHARTCHENKO, V.: DURCOVA-HILLS, G.; SCHERNTHANER, W.; STOJKOVIC, M.; REICHENBACH, H.D; MÜLLER, S.; STEINBORN, R;; MÜLLER, M; WENIGERKIND, H.; PRELLE, K.; WOLF, E; BREM, G: Potential of fetal germ cells for nuclear iransfer in cattle. Mol. Reprod, Dev. 52 (1999), 421-426

ZAKHARTCHENKO, V; DURCOVA-HILLS, G.; STOJKOVIC, M.; SCHERNTHANER, W.; PRELLE, K.; STEINBORN, R.; MÜLLER, M; BREM, G.; WOLF, E.: Effects of serum starvation and re-cloning on the efficiency of nuclear transfer using bovine fetal fibroblasts. J, Reprod. Fertile. 115 (1999), 325-331

ZAKHARTCHENKO, V;; MUELLER, S.; ALBERIO, R; SCHERNTHANER, W; STOJKOVIC، M: WENIGERKIND, H.; WANKE, R.; LASSNIG, C; MULLLER, M.; WOLF, E; BREM, G;:

Nuclear transfer in cattle with non-transfected and transfected fotal or cloned transgenic fetal and adult fibroblasts. Submitted, $200 \mathrm{t}$

Received: $2001-04-09$

Accepted: $2001-05-07$

\author{
Authors' addresses \\ Dr. BIRGIT KÜHHOLZER \\ Agrobiogen GmbH \\ Thalmannsdorf 25 \\ D-86567 Hilgertshausen \\ Germany
}

Prof. Dr. GOTTFRIED BREM

Ludwig Boltzmann Institut fur

zyto-, immuno- und molekulargenetische Forschung

Veterinärplatz I

A-1210 Wien

Austria 


\section{Buchbesprechung}

\section{Ziegenzucht}

\section{CHRISTIAN F, GALL}

2., völlig neubearbcitete Auflage, 501 Seiten, 20 Farbfotos auf Tafeln, 250 Abbildungen, 80 Tabellen, Verlag Eugen Ulmer, Stuttgart, 2001, ISBN 3-8001-4355-0, 128,00 DM

Ziegen gehören nicht nur zu den ăltesten Haustieren, sondern sie besitzen auch heute in vielen Lăndern, vor allem in Asien und Afrika, eine große Bedeutung für die Emăhrung und die Verbesserung der Einkommensverhallmisse der ländlichen Bevölkerung. In Deutschland ist ihre Anzahl in den letzten Jahren beträchtlich zuriłckgegangen. So werden gegenwärtig von etwa 10000 Haltern ca. 100000 Ziegen gehalten. Neben der Herdenhaltung sind es Zuchter und Halter, die als Landwirte oder im Nebenerwerb, Ziegen nutzen. Zurrehmend größer wird auch der Personenkreis, der diese Tiere aus Freude am Tier und am landwirtschaftlichen Leben in nicht nur landwirtschaftlich genutztem Umfeld hălt. Die große Sachkenntnis und langjahrige umfangreiche Erfahrungen des Autors mit dieser Tierart funden in der völlig neubearbeiteten, nummehr nach fast 20 Jahren, vorliegenden 2 . Auflage dieses Buches ihren konkreten Niederschlag. Dieses Standardwerk vermittelt den neuesten Stand der Ziegenzucht und haltung mit einer Fulle wissenswerter und notwendiger Informationen fur die Praxis. Ebenso ist es auf Grund der weltweiten Bedeutung der Ziegenhaltung das Bemblahen des Autors in den einzelnen Kapiteln auch die Aspekte der Ziegenhaltung in den Tropen und Subtropen zu berücksichtigen.

Der gegenwärtige Stand wissenschaftlich fundierter Kenntnisse und Erfahrungen wird informativ, ubersichtlich, gut verstăndlich und praxisnah, durch zahlreiche Abbildungen und Tabellen gut unterstutzl, vermittelt. Die ersten drei Kapitel widmen sich der Abstammung, Domestikation und Verbreitung, der Bedeutung und dem Umfang der Ziegenhaltung sowie den Besonderheiten der Anpassung der Ziege an die Umweltbedingungen. Es folgt das Kapitel uber dic Rassen, in welchem neben den in Deutschland und in Europa vertretenen, die vom Aussterben bedrohten sowie die in außereuropalischen Kontinenten gehaltenen, in Bild und Wort vorgestellt werden. Dem Kapitel zu Fragen der Fortpflanzung folgen die Nutzleistungen der Ziegen wie Milchproduktion und Verarbeitung, Fleischproduktion, Faserproduktion sowie Nebenprodukte und Nebenleistungen. Es folgen Haltung und Pflege, Futterung, Züchtung und Zuchtforderung in Deutschland sowie in europäischen und außereuropatischen Ländern. Das cbenfalls gut aberschaubar gegliederte Kapitel ober Krankheiten beschließt den Hauptteil des Buches. Ein Anhang informiert uber nützliche Adressen vielfältiger Art, die potentiellen Interessenten die Kontaktaufriahme zu Verbänden und Unternehmungen im In- und Ausland erleichtern sollen. Die jedem Kapitel angefügten Literaturhinweise ermogglichen es einzelnen Fragen im Detail nachzugehen.

Das Verzeichnis der Lehr- und Handbucher stellt nur eine Auswahl dar, wobei vom Rezensenten u.a. jungere, bedeutende Titel des Ulmer-Verlages zur Thematik, zum Beispiel von SAMBRAUS oder LÖHLE, vermisst werden.

Dieses Standardwerk gehört als Nachschlagewerk und Arbeitsanleitung in die Hand des Tierzllchters, auf Grund seiner großen Praxisrelevanz in die Hand des Ziegenhalters, aber auch in die Hand des an dieser Tierart interessierten Laien, der sich einen umfassenden Öberblick über den Nutzen und die Bedilrfnisse dieser liebenswerten Nutztiere verschaffen will. Uneingeschränkt ist dieses Handbuch Zuchtern, Haltern, Beratern, Entwicklungshelfern oder Studierenden sehr zu empfehlen. 